\title{
Mode of Action of Illudin S
}

\author{
J. WALSER AND P. F. HEINSTEIN \\ Department of Medicinal Chemistry and Pharmacognosy, School of Pharmacy, Purdue University, \\ West Lafayette, Indiana 47907
}

Received for publication 6 November 1972

\begin{abstract}
The effect of the antitumor antibiotic illudin $S$ on bacterial macromolecular synthesis was investigated. Illudin $S$ was found to be inhibitory to in vivo deoxyribonucleic acid (DNA) synthesis from thymidine. Ribonucleic acid (RNA) synthesis was inhibited only at a concentration of illudin S 10 times that which inhibited DNA synthesis. The rate of protein synthesis remained the same except for a brief initial inhibition. When thymidine triphosphate was used for in vitro DNA synthesis, inhibition by illudin S did not occur, as tested with partially purified DNA polymerase II from Escherichia coli pol $A_{1}{ }^{-}$, with $E$. coli DNA-dependent RNA polymerase, with $E$. coli pol $A_{1}{ }^{-}$spheroplasts, and with frozen and thawed Bacillus subtilis cells. A protein fraction isolated from $B$. subtilis capable of forming thymidine mono-, di-, and triphosphates from thymidine was not inhibited by illudin $\mathrm{S}$. Furthermore, ${ }^{14} \mathrm{C}$-illudin $\mathrm{S}$ taken up by $B$. subtilis cells was reisolated unchanged, making an intracellular activation of illudin $\mathbf{S}$ unlikely. Therefore, an attractive hypothesis is that illudin $\mathbf{S}$ inhibits DNA synthesis from thymidine which does not proceed through deoxyribonucleoside triphosphates, the generally accepted substrates for DNA synthesis.
\end{abstract}

Illudin $\mathrm{S}$ is an antibiotic produced by Clito cybe illudens (1). Its structure was shown $(8,9$, $11)$ to be that illustrated in Fig. 1. Illudin $S$ was independently isolated from Lampteromyces japonicus (12) and was called lampterol. In addition to inhibiting the growth of gram-negative and gram-positive bacteria and mycobacteria, this agent also showed antitumor activity $(9,13)$.

Illudin $\mathbf{S}$ possesses some unique structural features: a cyclopropane ring and an $\alpha, \beta$-unsaturated ketone function. Both functionalities are potentially good alkylating sites.

This paper describes the effect of illudin $\mathbf{S}$ on protein and nucleic acid synthesis in Bacillus subtilis and Escherichia coli cells, in bacterial cells made permeable to deoxyribonucleoside triphosphates, and in cell-free nuclei acid biosynthetic systems.

\section{MATERIALS AND METHODS}

Organisms. $C$. illudens (ATCC 11719) was grown at $25 \mathrm{C}$ in stationary cultures in corn steep medium (2) or in potato-dextrose broth. $E$. coli (ATCC 14948) was grown in nutrient broth at $37 \mathrm{C}$ on a rotary shaker $(260 \mathrm{rpm})$. B. subtilis (ATCC 6633) was grown in the medium described by Reusser (14). E. coli pol $A_{1}^{-}(6,7)$, a mutant that lacks deoxyribonucleic acid (DNA) polymerase I, was a gift from T. Kornberg, and was grown in Penassay Broth (7).

Chemicals. Thymidine-methyl- ${ }^{3} \mathrm{H} \quad\left({ }^{3} \mathrm{H}-\mathrm{T}\right)$ was purchased from International Chemical and
Nuclear Corp. Adenosine $-8-{ }^{14} C-5^{\prime}$ - triphosphate ${ }^{\left({ }^{4} \mathrm{C}-\mathrm{ATP}\right),}$ thymidine-methyl-8 $\mathrm{H}-5^{\prime}$-triphosphate ( $\left.{ }^{3} \mathrm{H}-T T P\right)$, uridine $-6-{ }^{3} \mathrm{H}\left({ }^{3} \mathrm{H}-\mathrm{U}\right)$, and leucine- $U$ ${ }^{14} \mathrm{C}$ were obtained from Amersham/Searle Corp. Some of the illudin $S$ used in the inhibition studies was generously supplied by M. Anchel; the remainder was isolated from the culture medium of $C$. illudens (1). ${ }^{14} \mathrm{C}$-labeled illudin $\mathrm{S}$ was prepared by feeding 3- to 4-week-old cultures of C. illudens with mevalonic acid-2 $-14 C(2)$. The ${ }^{14} \mathrm{C}$ illudin $S$ was extracted with chloroform (four times with an equal volume) from the culture medium and the homogenized mycelium. The combined extracts were concentrated to a small volume and purified by partition between water and chloroform on a Celite column. Moist Celite 545 was boiled with $1 \mathrm{~N} \mathrm{HCl,} \mathrm{washed} \mathrm{with} \mathrm{deionized} \mathrm{water}$ to neutrality, suspended in chloroform, and poured into a column $(2$ by $50 \mathrm{~cm})$. The infrared spectrum of the ${ }^{14} \mathrm{C}$-illudin $\mathrm{S}$ eluted from the column with chloroform was found to be identical to that of a known illudin $\mathrm{S}$ sample. Furthermore, no difference of migration of the isolated ${ }^{14} \mathrm{C}$-illudin $\mathrm{S}$ and an authentic sample could be observed on thin-layer chromatography plates (silica gel G). Two solvent systems were employed: chloroformacetone, $1: 1$, and benzene- $95 \%$ ethanol, $2: 1$. In both cases, the radioactivity coincided with the illudin $\mathrm{S}$ used as standard material.

Synthesis of macromolecules in vivo. Cellular nucleic acid and protein synthesis was studied by following the incorporation of the appropriate radioactively labeled precursors into acid-insoluble material. A $1-\mathrm{ml}$ sample from a $B$. 
<smiles>CC1=C2CC3(CC3)C(C)(O)C(=O)C2=CC(C)(CO)C1O</smiles>

Fig. 1. Structure of illudin $S$.

subtilis culture, grown overnight, was used to inoculate $25 \mathrm{ml}$ of medium. After $1 \mathrm{~h}$ at $37 \mathrm{C}$, radioactive precursor wंas added ( ${ }^{3} \mathrm{H}-\mathrm{T}$ for DNA synthesis, ${ }^{\mathrm{s}} \mathrm{H}-\mathrm{U}$ for ribonucleic acid [RNA] synthesis, and leucine- $U-14 C$ for the formation of protein); $10 \mathrm{~min}$ thereafter, the culture was divided. Half was used as a control, and to the other half illudin $S$ (5 to $150 \mu \mathrm{g} / \mathrm{ml}$ ) was added. Samples were withdrawn from the cultures at appropriate time intervals (see figures). The reaction was stopped by the addition of ice-cold $10 \%$ trichloroacetic acid (equal volume), and the acid-insoluble material was collected on a $0.45-\mu \mathrm{m}$ membrane filter (Millipore Corp.). The precipitate was washed three times with ice-cold $5 \%$ trichloroacetic acid, dried, and counted in $10 \mathrm{ml}$ of Bray's solution in a Beckman LS-100 liquid scintillation counter, with a counting error of $2 \%$.

${ }^{3} \mathrm{H}-\mathrm{T}$ uptake by the cells was compared with 'H-T incorporation into DNA by performing the experiment in the same manner as described above except that the samples taken from the incubation mixture were filtered immediately without trichloroacetic acid treatment. The collected cells were washed three times with fresh medium; they were then dried and radioactivity was determined as above.

In some in vivo incorporation experiments, ${ }^{14} \mathrm{C}$ illudin $\mathrm{S}\left(12.5 \mu \mathrm{g} / \mathrm{ml}, 1.26 \times 10^{\circ}\right.$ counts $\left./ \mathrm{min}\right)$ together with 'H-T was fed to a 60-ml B. subtilis culture, inoculated with $5 \mathrm{ml}$ from an overnight culture. After $2 \mathrm{~h}$ at $37 \mathrm{C}$ in a shaker, the cells were harvested by centrifugation, suspended in $0.1 \mathrm{M}$

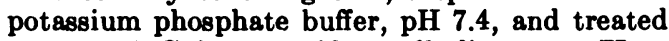
at 0 to $4 \mathrm{C}$ in a sonifier cell disruptor (Heat System Co.) for $1 \mathrm{~min} / \mathrm{ml}$ at a maximal output setting. The broken cell suspension was extracted three times with equal volumes of ethylacetate and three times with equal volumes of chloroform. The extracts were combined, concentrated, and analyzed by thin-layer chromatography (see above). The aqueous phase was passed through a G-150 Sephadex column ( 2 by $45 \mathrm{~cm})$, and the radioactivity was determined in each of the 6-ml fractions collected.

Spheroplast formation. Preparation of frozen B. subtilis cells and the incorporation of 'H-TTP into DNA were carried out as described by Billen et al. (3). Illudin $\mathrm{S}$ was added to the incubations at a concentration of $40 \mu \mathrm{g} / \mathrm{ml}$. The method of Smith et al. (16) was used to prepare spheroplasts from
E. coli pol $A_{1}^{-}$and to study incorporation of ${ }^{8} \mathrm{H}-$ TTP into DNA with and without illudin S.

Synthesis of DNA and RNA in vitro. DNAdependent RNA polymerase from $E$. coli was isolated by one of the two methods described by Burgess (5). The enzyme obtained after the two glycerol gradient centrifugations (see 5) was utilized and assayed (5) with and without illudin S. DNA polymerase II from $E$. coli pol $A_{1}^{-}$was partially purified (7). The active protein fraction, after the two glycerol gradient centrifugations (low and high salt), was used as an enzyme source and assayed according to Kornberg and Gefter (7), with and without illudin $S$.

Phosphorylation of thymidine in vitro. The cells ( $5 \mathrm{~g}$, wet weight) from an overnight culture of $B$. subtilis were washed twice with $0.1 \mathrm{M}$ tris(hydroxymethyl)aminomethane - hydrochloride, pH 7.5, containing $1 \mathrm{mM}$ ethylenediaminetetraacetate (EDTA) and $5 \mathrm{mM}$ mercaptoethanol (one-tenth the volume of the original medium). After being suspended in $3 \mathrm{ml}$ of the same buffer per $100 \mathrm{ml}$ of original culture medium, the cells were sonically treated for $30 \mathrm{~s} / \mathrm{ml}$ (output setting: 7). The sonically treated solution was centrifuged at $13,000 \times g$ for $30 \mathrm{~min}$, and the supernatant fluid was used for the phosphorylation of thymidine experiment. All operations were carried out at 0 to $4 \mathrm{C}$.

The assay mixture was identical to that described by Masui and Garren (10); however, the amount of phosphorylated thymidine derivatives produced was determined by use of diethylaminoethyl-cellulose paper disks, and the washing procedure of Shiosaka et al. (15) was used. The products of this reaction were identified by descending paper chromatography with the system isobutyric acid-ammonia-EDTA (4) and were found to be mainly thymidine monophosphate (TMP) and small amounts of thymidine di- and triphosphates (TDP and TTP).

\section{RESULTS}

Effect of illudin $S$ on protein and nucleic acid synthesis in vivo. Incorporation of leucine into acid-insoluble material (Fig. 2) was inhibited temporarily upon addition of illudin $\mathbf{S}$. However, after $10 \mathrm{~min}$, protein synthesis continued at a rate identical to that in the control incubations. RNA synthesis, as measured by the incorporation of uridine into acid-insoluble material, was inhibited $95 \%$ at rather high concentrations of illudin S (Fig. 3). Incorporation of thymidine into DNA, however, was almost completely stopped by illudin $S$ at a concentration of $10 \mu \mathrm{g} / \mathrm{ml}$ (Fig. 4). Furthermore, inhibition occurred immediately after the addition of illudin S. Similarly, DNA synthesis was inhibited by illudin $\mathrm{S}$ in the $E$. coli pol $A_{1}^{-}$mutant (Fig. 5). 


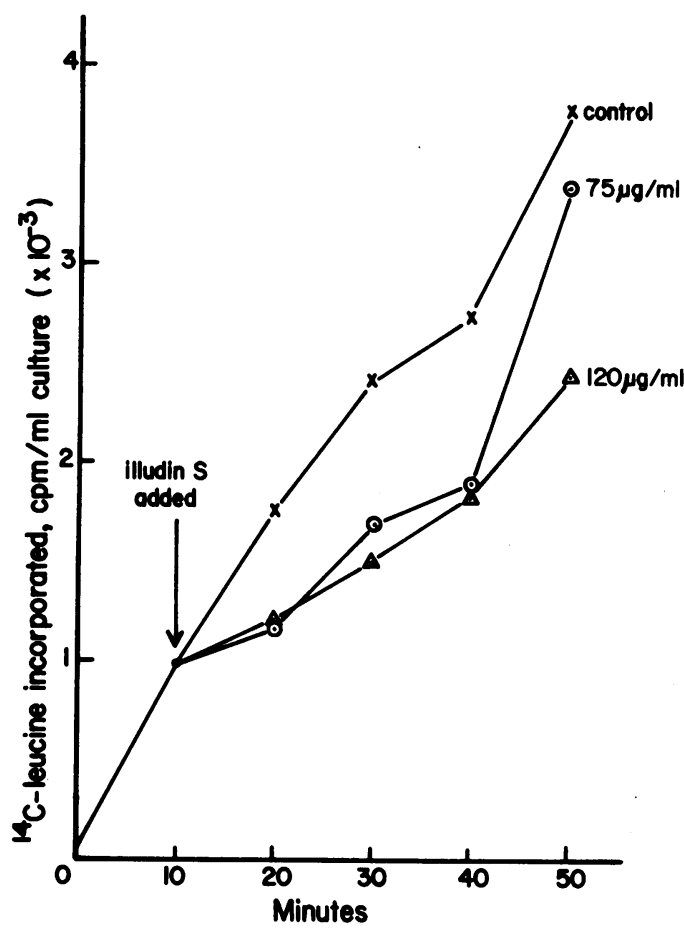

Fig. 2. Effect of illudin $S$ on the formation of protein in $B$. subtilis cells, as measured by the incorporation of ${ }^{14} \mathrm{C}$-leucine into acid-insoluble material. The addition of illudin $S$ is shown by the arrow, and the concentrations of illudin $S$ are given after the appropriate curves.

This mutant has been reported to lack DNA polymerase I $(6,7)$.

To test the possibility that illudin $\mathbf{S}$ was inhibiting the transport of thymidine into $B$. subtilis cells, we measured thymidine uptake as well as incorporation of thymidine into acidinsoluble material. Although illudin S immediately inhibited incorporation of thymidine into DNA (Fig. 6), the uptake of thymidine continued for $10 \mathrm{~min}$ after addition of illudin $\mathrm{S}$. DNA synthesis from TTP in $B$. subtilis cells frozen for $11 \mathrm{~h}$ was found to be no longer sensitive to illudin S. As can be seen in Fig. 7, the incorporation of 'H-TTP into DNA was not inhibited by $100 \mu \mathrm{g}$ of illudin $\mathrm{S} / \mathrm{ml}$ but rather was slightly stimulated.

Spheroplasts of $E$. coli pol $A_{1}-$ were prepared (16), and DNA synthesis was measured with and without illudin $\mathrm{S}$. The results in Table 1 showed no inhibition by illudin S of ${ }^{\mathrm{B}} \mathrm{H}$-TTP incorporation into acid-insoluble material, even at twice the illudin $\mathrm{S}$ concentrations which

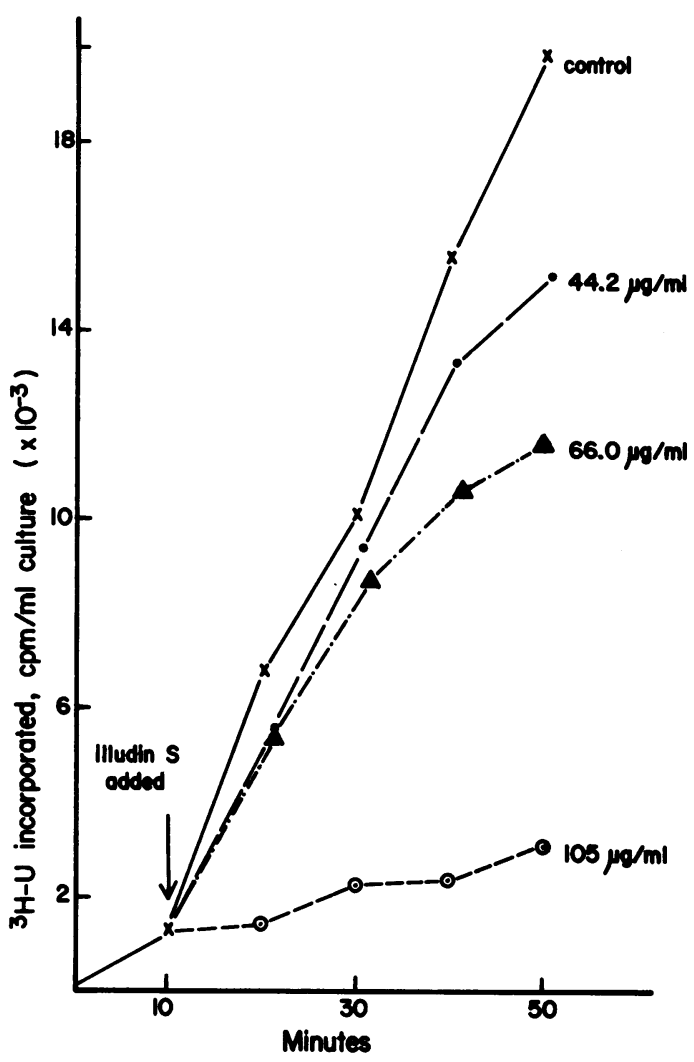

FIG. 3. Synthesis of $R N A$ in B. subtilis cells, as measured by the incorporation of uridine $-5-{ }^{3} H$ into acid-insoluble material. The addition of illudin $S$ is shown by the arrow, and the concentrations of illudin $S$ are given after the appropriate curves.

inhibited thymidine incorporation into DNA in intact cells (Fig. 5).

In vitro inhibition studies. DNA-dependent RNA polymerase, isolated from $E$. coli (5), was not affected by illudin $\mathrm{S}$ (Table 2). For comparison, actinomycin $\mathrm{D}$ readily inhibited the partially purified enzyme at a concentration one-tenth that of illudin S. A number of variations were incorporated into the experiment: preincubation of illudin $\mathbf{S}$ with the RNA polymerase, preincubation of the illudin $\mathrm{S}$ with different amounts of calf thymus DNA, used as template, and incubations with illudin $S$ at different stages of enzyme purification. In none of the above experimental designs was inhibition of DNAdependent RNA polymerase by illudin $\mathrm{S}$ observed.

DNA-dependent DNA polymerase II from the DNA polymerase I-deficient $E$. coli mutant 


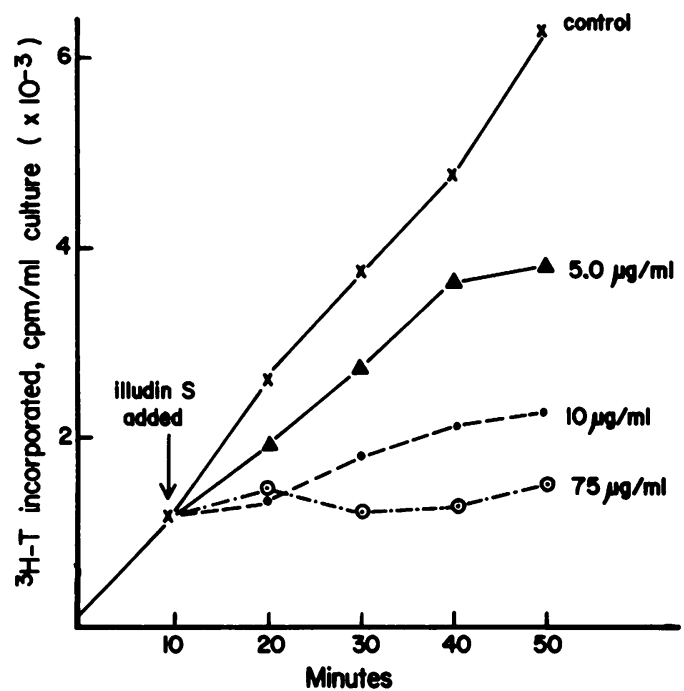

Fic. 4. Synthesis of DNA in B. subtilis cells, as measured through the incorporation of thymidinemethyl- ${ }^{3} \mathrm{H}$ into acid-insoluble material. The addition of illudin $S$ is shown by the arrow, and the concentrations of illudin $S$ are given after the appropriate curves.

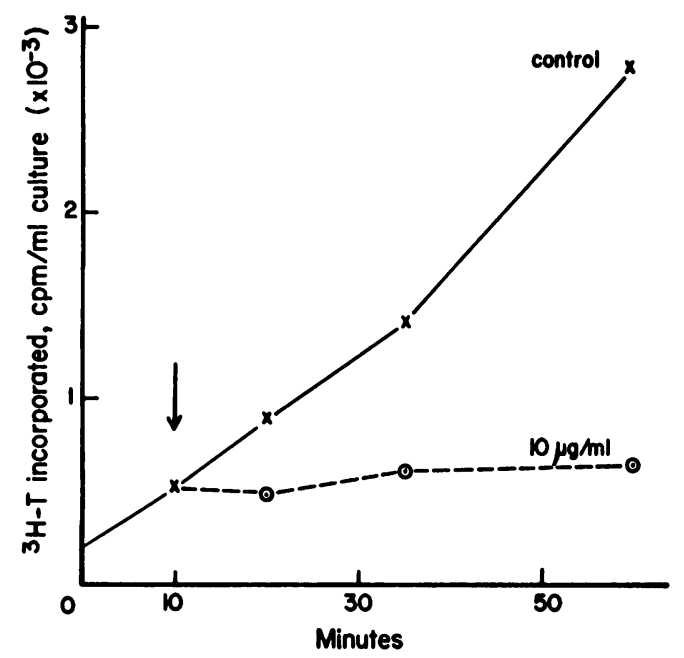

FIG. 5. Inhibition of DNA synthesis from thymidine-methyl-3 $\mathrm{H}$ in $E$. coli pol $A_{1}^{-}$, a mutant which lacks DNA polymerase I. The tritiated substrate was added at zero time, and the illudin $S$ was added to one culture after $10 \mathrm{~min}$ (arrow) at a concentration of $10 \mu \mathrm{g} / \mathrm{ml}$.

pol $A_{1}{ }^{-}$was not inhibited by illudin $S$ at a concentration of $50 \mu \mathrm{g} / \mathrm{ml}$ (Table 3), which was five times the concentration causing virtually complete inhibition of in vivo DNA synthesis

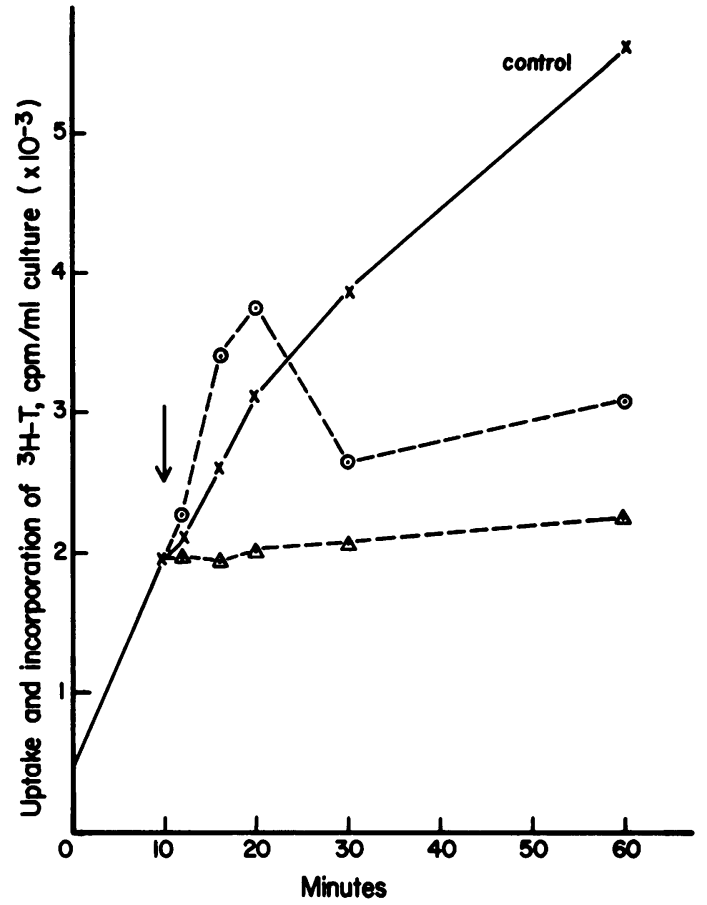

FIG. 6. Effect of illudin $S$ on thymidine-methyl${ }^{3} \mathrm{H} \quad\left({ }^{3} \mathrm{H}-\mathrm{T}\right)$ uptake and incorporation into acidinsoluble material in $B$. subtilis. ${ }^{3} H-T$ was added at zero time, and after $10 \mathrm{~min}$ illudin $S(50 \mu \mathrm{g} / \mathrm{ml})$ was added (arrow). Thereafter, samples were taken and immediately filtered (uptake of ${ }^{\mathrm{s}} \mathrm{H}-\mathrm{T}, \odot$ ); identical samples were pipetted into equal volumes of $10 \%$ trichloroacetic acid (incorporation of ${ }^{3} \mathrm{H}-\mathrm{T}$, $\Delta)$.

(Fig. 5). Variations in addition of enzyme, template, and illudin $\mathrm{S}$ and use of different preincubation times (see above for RNA polymerase) showed no inhibition of DNA synthesis by illudin S.

To eliminate the possibility that illudin $\mathrm{S}$ inhibits the conversion of thymidine to TMP, TDP, or TTP, we prepared a cell-free preparation of $B$. subtilis which could carry out this conversion. However, as shown in Table 4, the conversion was not inhibited by illudin $S$.

Fate of ${ }^{14} \mathrm{C}$-illudin $S$ in $B$. subtilis cells. Of the ${ }^{14} \mathrm{C}$-illudin $\mathrm{S}$ fed to a $B$. subtilis culture, approximately $70 \%$ was absorbed by the cells (Table 5). Most of the absorbed illudin S (41.3\%) was bound to macromolecules, as shown by molecular sieve chromatography (Sephadex G-150), and could not be extracted with either ethylacetate or chloroform. Some of the illudin $S$ absorbed by the $B$. subtilis cells was apparently 


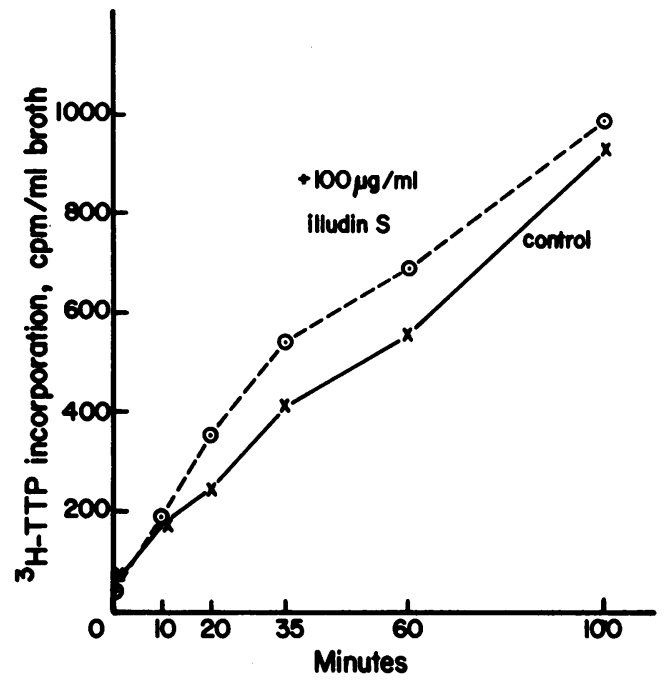

FIG. 7. Effect of illudin $S$ on DNA synthesis in $B$. subtilis spheroplasts, formed by freezing in a sodium citrate buffer according to Billen et al. (\$). Assay mixtures were identical to those of Billen et al. (\$), with the exception that $0.5 \mu \mathrm{Ci}$ of ${ }^{8} \mathrm{H}-\mathrm{TTP}$ was used, and to one incubation $100 \mu g$ of illudin $S / m l$ was added at zero time $(\odot)$.

TABLE 1. Effect of illudin S on DNA synthesis in E. coli pol $A_{1}^{-}$spheroplasts ${ }^{a}$

\begin{tabular}{c|c|c}
\hline Sample & $\begin{array}{c}\text { TTP incorpora- } \\
\text { tion (counts per } \\
\text { min per sample) }\end{array}$ & $\begin{array}{r}\text { Percentage } \\
\text { of control }\end{array}$ \\
\hline $\begin{array}{c}\text { Control ............ } \\
\text { Illudin S }\end{array}$ & 1,289 & 100.0 \\
$2 \mu \mathrm{g} / \mathrm{ml} \ldots \ldots \ldots \ldots$ & 1,676 & 130.0 \\
$20 \mu \mathrm{g} / \mathrm{ml} \ldots \ldots \ldots \ldots$ & 1,250 & 96.9 \\
$100 \mu \mathrm{g} / \mathrm{ml} \ldots \ldots \ldots$ & 1,794 & 139.2 \\
\hline
\end{tabular}

a Spheroplast formation and assay mixtures $(0.2 \mathrm{ml})$ were those described by Smith et al. (16), with the following exceptions: $0.01 \mathrm{M}$ mercaptoethanol (instead of $0.1 \mathrm{mM}$ dithiothreitol) and $0.5 \mu \mathrm{Ci}$ of ${ }^{3} \mathrm{H}-\mathrm{TTP}$ as substrate.

present in a free form in the cell and could be extracted with ethylacetate and chloroform. Chromatographic comparison of the extracted ${ }^{14} \mathrm{C}$-illudin $\mathrm{S}$ with the original fed ${ }^{14} \mathrm{C}$-illudin $\mathrm{S}$ showed no difference in migration in two different solvent systems.

\section{DISCUSSION}

Illudin $\mathbf{S}$ inhibited macromolecular synthesis in intact $B$. subtilis cells. From the observation that DNA synthesis was preferentially and immediately inhibited compared with RNA and protein synthesis, we concluded that illudin S has a direct effect on the incorporation of thy-

TABLE 2. Effect of illudin $S$ on cell-free RNA synthesisa

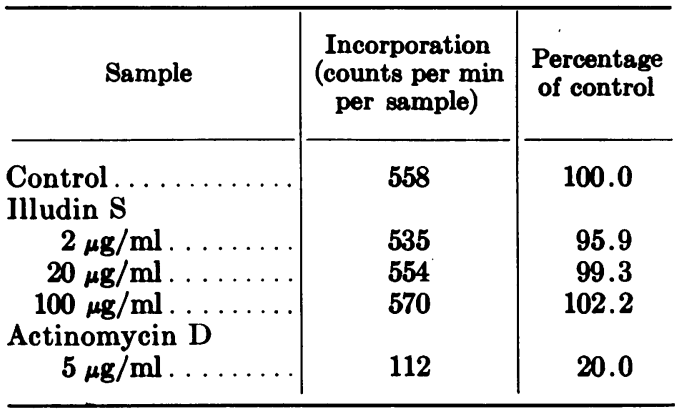

a RA polymerase was isolated from $E$. coli and assayed according to Burgess (5). Activity was measured by the incorporation of ${ }^{14} \mathrm{C}-\mathrm{ATP}$ (0.15 mM, $1 \mu \mathrm{Ci} / \mu$ mole).

TABLE 3. Effect of illudin $S$ on cell-free DNA synthesis ${ }^{a}$

\begin{tabular}{c|c|c}
\hline Sample & $\begin{array}{c}\text { Incorporation } \\
\text { (pmoles of } \\
{ }^{8} \text { H-TTP) }\end{array}$ & $\begin{array}{c}\text { Percentage } \\
\text { of control }\end{array}$ \\
\hline $\begin{array}{c}\text { Control ............ } \\
\text { Illudin S }\end{array}$ & 11.45 & 100.0 \\
$15 \mu \mathrm{g} / \mathrm{ml} \ldots \ldots \ldots \ldots$ & 13.85 & 121.0 \\
$50 \mu \mathrm{g} / \mathrm{ml} \ldots \ldots \ldots \ldots$ & 13.90 & 121.4 \\
\hline
\end{tabular}

a DNA polymerase II was isolated from $E$. coli pol $A_{1}^{-}$and assayed according to Kornberg and Gefter (7).

TABLE 4. Effect of illudin $S$ on the phosphorylation of thymidine in cell-free extracts of $B$. subtilis ${ }^{a}$

\begin{tabular}{c|c|c}
\hline Sample & $\begin{array}{c}{ }^{3} \text { H-thymidine } \\
\text { incorporation } \\
\text { (nmoles } / \mathbf{m g} \\
\text { of protein) }\end{array}$ & $\begin{array}{c}\text { Percentage } \\
\text { of control }\end{array}$ \\
\cline { 1 - 2 } Control . . . . . . . . & 32.52 & 100.0 \\
Illudin S & & \\
$10 \mu \mathrm{g} / \mathrm{ml} \ldots \ldots \ldots \ldots$ & 32.56 & 100.1 \\
$25 \mu \mathrm{g} / \mathrm{ml} \ldots \ldots \ldots \ldots$ & 33.40 & 102.7 \\
$50 \mu \mathrm{g} / \mathrm{ml} \ldots \ldots \ldots$ & 31.44 & 96.7 \\
$100 \mu \mathrm{g} / \mathrm{ml} \ldots \ldots \ldots \ldots$ & 31.92 & 98.2 \\
\hline
\end{tabular}

a A sonic extract of $B$. subtilis served as the enzyme source. The incubation mixture was identical to that described by Masui and Garren (10). Phosphorylated products of ${ }^{2} \mathrm{H}$-thymidine were determined by absorption on diethylaminoethyl-cellulose paper disks (15). 
TABLe 5. Distribution of "C-illudin S in B. subtilis cellsa

\begin{tabular}{c|cc|c}
\hline Sample & $\begin{array}{r}\text { Radioactivity } \\
\text { (counts/min) }\end{array}$ & $\begin{array}{c}\text { Percent- } \\
\text { age of } \\
\text { original }\end{array}$ \\
\hline${ }^{14} \mathrm{C}$-illudin S fed ........ & $12.6 \times 10^{4}$ & 100 \\
$\begin{array}{r}{ }^{14} \mathrm{C} \text { recovered in medium. } \\
{ }^{14} \mathrm{C} \text { in organic phase of } \\
\text { cell sonic extract...... }\end{array}$ & $3.73 \times 10^{4}$ & 18.0 \\
${ }^{14} \mathrm{C}$ in aqueous phase of \\
cell sonic extract..... & $5.2 \times 10^{4}$ & 41.3 \\
\hline
\end{tabular}

a ${ }^{14} \mathrm{C}$-illudin $\mathrm{S}$ was added to a $B$. subtilis culture; after $2 \mathrm{~h}$, the cells were harvested, sonically treated and extracted three times with equal volumes of ethylacetate and chloroform ${ }^{14} \mathrm{C}$ in organic phase of cell sonic extract). The residue (aqueous phase) of this extraction was used to determine ${ }^{14} \mathrm{C}$ in aqueous phase of cell sonic extract. Similarly, the medium was extracted three times with equal volumes of ethylacetate and chloroform ( ${ }^{14} \mathrm{C}$ recovered in medium). Negligible amounts (less than $2 \%$ ) of radioactivity were obtained from the aqueous residue of the medium.

midine into DNA. However, this inhibition was no longer apparent when $B$. subtilis cells were made permeable to TTP and when TTP was utilized for DNA synthesis. Furthermore, isolated RNA polymerase and DNA polymerase II were not inhibited by illudin $S$, which excluded inhibition of DNA synthesis through the alkylation by illudin $\mathbf{S}$ of the DNA template used by both enzymes. Since one of the differences between the in vivo and in vitro experiments was the partial (spheroplast formation) or complete (isolated RNA and DNA polymerase) removal of the cell wall of $B$. subtilis, the possibility existed that the uptake of thymidine was inhibited by illudin $S$, or that during the uptake of illudin $S$ by $B$. subtilis cells the compound underwent a metabolic change and the product of this reaction was the active inhibitor. Both possibilities could be excluded because uptake of thymidine continued for at least $10 \mathrm{~min}$ after addition of illudin $\mathrm{S}$, whereas DNA synthesis was immediately inhibited, and because ${ }^{14} \mathrm{C}$-illudin $\mathrm{S}$ taken up by $B$. subtilis cells was found to be unchanged. This, therefore, focused attention on the other difference between the in vivo and in vitro experiments, namely, the difference in substrates. In the in vivo experiments, thymidine was used as substrate for DNA synthesis, whereas TTP served as precursor for in vitro experiments (including spheroplasts). Although the incorporation of thymidine into DNA was inhibited by illudin S, no inhibition was observed when TTP served as the substrate. This difference was not due to the phosphorylation of thymidine, because a cell-free preparation which could catalyze the formation of TMP, TDP, and TTP from thymidine was not inhibited.

From the above results, therefore, it is tempting to postulate the existence of two DNA-synthesizing systems in B. subtilis: one utilizing thymidine directly for DNA synthesis through a so far unknown DNA precursor and the conventional DNA-synthesizing system utilizing TTP. In this case, illudin $S$ could inhibit the formation of the unknown DNA precursor from thymidine or its incorporation into DNA. Similar conclusions have been drawn by others (3), from the observation that in $B$. subtilis ultraviolet light inhibits thymidine incorporation into DNA, but not synthesis of DNA from TTP. Similarly, Werner (17) concluded from experiments with $E$. coli that thymidine is incorporated into DNA by a different route than the deoxyribonucleotide triphosphates.

Similar results have been obtained with the bactericidal drug nalidixic acid (18). This agent appears to inhibit in vivo DNA synthesis in $E$. coli and $B$. subtilis, but does not affect cell-free synthesis of DNA by DNA polymerase I or incorporation of TTP into DNA in bacterial cells made permeable to the deoxynucleoside triphosphates (16).

\section{ACKNOWLEDGMENTS}

We are grateful to $M$. Anchel for the generous supply of illudin $\mathbf{S}$ and to $\mathbf{T}$. Kornberg for the $\boldsymbol{E}$. coli mutant $\operatorname{pol} A_{1}{ }^{-}$.

This investigation was supported by a grant from the Purdue University Cancer Research Committee.

\section{LITERATURE CITED}

1. Anchel, M., A. Hervey, and W. J. Robbins. 1950. Antibiotic substances from Basidiomycetes. VII. Clitocybe illudens. Proc. Nat. Acad. Sci. U.S.A. 36:300-305.

2. Anchel, M., T. C. McMorris, and P. Singh. 1970. The biogenesis of illudin $\mathbf{S}$ and $\mathbf{M}$ in Clitocybe illudens. Phytochemistry 9:2339-2343.

3. Billen, D., L. B. Correira, and S. Silverstein. 1971. Utilization of deoxyribonucleoside triphosphates in the cellular synthesis of DNA by Bacillus subtilis. Biochem. Biophys. Res. Commun. 43: 1150-1157.

4. Bollum, F. J., and V. R. Potter. 1959. Nucleic acid metabolism in regenerating rat liver. VI. Soluble enzymes which convert thymidine to thymidine phosphate and DNA. Cancer Res. 19:561-565.

5. Burgess, R. R. 1969. A new method for the large scale purification of Escherichia coli deoxyribonucleic acid-dependent ribonucleic acid polymerase. J. Biol. Chem. 244:6160-6167. 
6. Delucia, P., and J. Cairns. 1969. Isolation of an $E$. coli strain with a mutation affecting DNA polymerase. Nature (London) 244:1164-1166.

7. Kornberg, T., and M. L. Gefter. 1970. DNA synthesis in cell-free extracts of a DNA polymerase-defective mutant. Biochem. Biophys. Res. Commun. 40:1348-1355.

8. McMorris, T. C., and M. Anchel. 1963. The structure of the basidiomycete metabolites illudin $\mathbf{S}$ and illudin M. J. Amer. Chem. Soc. 85:831-832.

9. McMorris, T. C., and M. Anchel. 1965. Fungal metabolites. The structure of the novel sesquiterpenoids illudin $\mathbf{S}$ and $\mathbf{M}$. J. Amer. Chem. Soc. 87:1594-1600.

10. Masui, H., and L. D. Garren. 1970. On the mechanism of action of adrenocorticotropic hormone. Stimulation of deoxyribonucleic acid polymerase and thymidine kinase activities in adrenal glands. J. Biol. Chem. 245:2627-2632.

11. Matsumoto, T., H. Shirahama, A. Ichihara, Y. Fukuoka, $Y$. Takahashi, $Y$. Mori, and $M$. Watanabe. 1965. The structure of lampterol (illudin S). Tetrahedron 21:2671-2676.

12. Nakanishi, K., Ohashi, N. Sujuki, M. Tada, Y. Yamada, and S. Inagaki. 1963. Isolation of lampterol from Lampteromyces japonicus (Kawam.) Sign. J. Pharm. Soc. Jap. 83:377-380.

13. Nakanishi, K., Ohashi, M. Tada, and Y. Yamada. 1965. Illudin $\mathrm{S}$ (lampterol). Tetrahedron 21: 1231-1246.

14. Reusser, F. 1968. Mode of action of melinacidin, an inhibitor of nicotinic acid biosynthesis. $J$. Bacteriol. 96:1285-1290.

15. Shiosaka, T., Y. Omura, H. Okuda, and S. Fujii. 1970. Activation of thymidine kinase of adult rat liver by the culture filtrate of Clostridium perfringens. Biochim. Biophys. Acta 204:352-358.

16. Smith, D. W., H. E. Schaller, and F. J. Bonhoeffer. 1970. DNA synthesis in vitro. Nature (London) 226:711-713.

17. Werner, R. 1971. On the mechanism of DNA synthesis in bacteria, p. 25-45. In D. W. Ribbons, J. F. Woessner, and J. Schultz (ed.), Nucleic acid-protein interactions and nucleic acid synthesis in viral infection. American Elsevier Publishing Co., Inc., New York.

18. Winshell, E. B., and H. S. Rosenkranz. 1970. Nalidixic acid and the metabolism of Escherichia coli. J. Bacteriol. 104:1168-1175. 